Teologia i Moralność, Volumen 15(2020), numer 2(28)

doi: 10.14746/tim.2020.28.2.06

ORCID: 0000-0001-5134-4741

ANDRZEJ SZAFULSKI

Papieski Wydział Teologiczny we Wrocławiu

\title{
Papież Franciszek wobec problemu alienacji i osamotnienia osób starszych
}

Rzeczywistością stale aktualną dla ludzi jest starość, a w obecnym czasie jeszcze wyraźniej odczuwalną, gdy nasiliło się zjawisko starzenia się ludności. Przyczynia się do tego malejący przyrost naturalny, a także wydłużenie trwania życia dzięki wielu sprzyjającym czynnikom, takim jak: wzrost dobrobytu, większy dostęp do opieki medycznej i zabezpieczenia socjalnego, wzrost oświaty ogólnej i zdrowotnej, lepsze warunki socjalnobytowe, aktywność społeczna ${ }^{1}$. Wydłużanie się ludzkiego życia, a także dramatyczny spadek urodzeń - szczególnie w krajach europejskich - spowodowały skok demograficzny, który sprawił, że systematycznie wzrasta liczba ludzi starszych, a liczba młodych nieustannie spada.

O ile niemal wszyscy ludzie chcą dożyć sędziwej starości, to nikt już nie chce być stary. Takie podejście wiąże się z pewnym stereotypem starości, jaki dominuje w dzisiejszym świecie. Starość bowiem postrzega się jako schyłek ludzkiego życia, charakteryzujący się nieporadnością i poczuciem społecznej nieużyteczności.

Najboleśniejszym faktem jest - zauważa z niepokojem papież Franciszek - że dzisiejsze społeczeństwo często nie widzi miejsca dla osób starszych. Starsi często spotykają ludzi, którzy przechodzą obok nich nieuważnie i obojętnie, wzbudzając w ten sposób poczucie, że są zbędni i niepotrzebni. Właśnie temu zagadnieniu poświęca wiele swej uwagi ojciec święty. W celu ukazania zakreślonego tematu najpierw należy ukazać sytuację osoby starszej w prze-

\footnotetext{
${ }^{1}$ Przez starość rozumie się okres w rozwoju człowieka po ukończeniu 60.-65. roku życia, ponieważ właśnie wtedy uaktywniają się zjawiska fizyczne, psychiczne i społeczne właściwe dla starości. Mimo że jest to proces naturalny, zależy od wielu czynników, jak choćby genetyki organizmu czy też od polityki społeczno-socjalnej społeczeństwa (Halicka 1999, 139).
} 
strzeni społecznej. Z kolei trzeba dostrzec wskazania papieża, który pragnie dowartościować seniorów. Należy zatem podkreślić ich wartość i przydatność w życiu społecznym. Trzeba także okazać solidarność z osobami starszymi. Papieżowi zależy również na nowym wymiarze pracy duszpasterskiej z osobami starszymi.

\section{Osoba starsza w przestrzeni społecznej}

Każdy etap życia człowieka ma swoje bogactwo i swoją nędzę, swoje zwycięstwa i klęski. Dzieciństwo to jedyny czas od narodzin do śmierci, w którym celem bytowania małego człowieka jest zabawa, czysta miłość. Młodość to wiek pochopnych decyzji, przegapionych szans i niszczącej kontestacji, dojrzałość - wiek owocowania rodzinnego i zawodowego, przydatności społecznej i godności osobistych. Równocześnie to w tym okresie człowiek często żegna się z ideałami, które jeszcze niedawno wyznawał całym sercem. Ostatni okres życia człowieka - starość - ma dziś „najgorszą prasę”. Najczęściej ten temat przemilcza się, jeśli zaś jest podejmowany, to najczęściej z punktu widzenia strategii socjalnej i w stylistyce zewnętrznej: „Coś z nimi trzeba zrobić: zapewnić byt, opiekę”. Obecna epoka kulturowa boi się starości ${ }^{2}$. Świat nie chce o niej słyszeć ${ }^{3}$. Zauważa to trafnie papież Franciszek: „dopóki jesteśmy młodzi, mamy tendencję do niemyślenia o starości, jakby to była choroba, od której trzeba trzymać się z dala" (Franciszek 2017).

Jednakże w XXI wieku starość stała się jedną z cech charakterystycznych ludzkości. Papież Franciszek, który osiągnął 78 rok życia, jest świadomy tego, że wchodzi w wiek podeszły, i temu się nie opiera. W katechezie podczas audiencji generalnej, poświęconej ludziom starszym, podkreśla: „Kiedy byłem na Filipinach ludzie witali mnie, nazywając: „Lolo Kiko, czyli dziadek Franciszek" (Franciszek 2016). Ponadto z uznaniem ocenia decyzję Benedykta XVI o poświęceniu ostatniego etapu życia modlitwie. „W sposób szczególny dziękuję Papieżowi seniorowi Benedyktowi XVI za jego obecność. Mówiłem już wiele razy, że bardzo się cieszę, że zamieszkał tu, w Watykanie, ponieważ jest to tak, jakby mieć mądrego dziadka w domu” (Franciszek 2016).

2 Gerentologowie w swoich pracach opisują cechy właściwe starości. W rzędzie cech negatywnych m.in. wymienia się , nieuchronne zmiany", w których ujawnia się proces biologicznego zniedołężnienia, widocznego ubytku sprawności fizycznej, różne patologie określane ogólnie jako „wielochorobowość”, pełne niekiedy bolesnych i długotrwałych cierpień. Wraz z tymi zmianami idzie postępujące otępienie umysłowe, poczucie osamotnienia, zepchnięcia na margines życia, postępująca z czasem niezaradność życiowa (Ślipko 1999, 18).

${ }^{3}$ Ludzie w większości chcą być młodzi lub przynajmniej czuć się młodo czy choćby młodo wygląadać. Nastawienie takie wynika z fałszywej ideologii obecnych czasów mającej zakorzenienie w kulcie postępu i sprawności oraz w przekonaniu o samowystarczalności człowieka. 
Ojciec święty podczas spotkania $\mathrm{z}$ uczestnikami międzynarodowego kongresu poświęconego duszpasterstwu osób w podeszłym wieku wyraźnie stwierdza: „Na przestrzeni niewielu dziesięcioleci piramida demograficzna - która niegdyś opierała się na dużej liczbie dzieci i ludzi młodych, a na jej szczycie było niewiele osób starszych - odwróciła się. O ile kiedyś ludzie starsi mogliby zaludnić małe państwo, o tyle dziś mogliby zaludnić cały kontynent. W tym sensie niezwykle liczna obecność osób w podeszłym wieku stanowi nowość dla każdego środowiska społecznego i geograficznego świata" (Franciszek 2020). Sytuacja ta spowodowana jest wydłużaniem się ludzkiego życia, a także dramatycznym spadkiem urodzeń - szczególnie w krajach europejskich, co spowodowało skok demograficzny i sprawiło, że wzrasta systematycznie liczba starszych, a liczba młodych nieustannie spada. Stwarza to problemy natury społecznej, kulturowej, psychologicznej i duchowej (Zwoliński 2005, 494).

Analizując tę sytuację, papież stwierdza, że „choć (dzięki postępowi medycyny) życie stało się dłuższe, to społeczeństwo nie stało się «pojemniejsze» dla życia! Liczba osób starszych znacznie się zwiększyła, ale niestety nasze społeczeństwa nie przeorganizowały się w wystarczający sposób, by zrobić dla nich miejsce z właściwym szacunkiem, rzeczywiście uwzględniając ich słabość i godność” (Franciszek 2017).

Obecnie obserwuje się zachwianie pozycji ludzi starszych w społeczeństwie. Wynikają stąd poważne trudności, które często przygniatają ludzi starszych, od najskromniejszej nędzy, zwłaszcza w krajach, gdzie nie ma żadnego zabezpieczenia na starość, do przymusowej bezczynności emerytów i do gorzkiej samotności ludzi odczuwających brak przyjaźni i pozbawionych prawdziwego ciepła rodzinnego. Gdy z przybywaniem lat ubywa sił i gdy jeszcze dołączy się jakaś choroba, coraz bardziej daje się we znaki słabość fizyczna, a przede wszystkim ciężar życia (Duda 2013, 71). Dostrzegając ten stan rzeczy, papież stwierdza: „Kiedy się starzejemy, zwłaszcza jeśli jesteśmy ubodzy, jeśli jesteśmy chorzy i samotni, odczuwamy skutki braków społeczeństwa nastawionego na skuteczność, które w konsekwencji ignoruje osoby starsze" (Franciszek 2017). Na Zachodzie badacze przedstawiają obecne stulecie jako wiek starzenia: liczba dzieci się zmniejsza, starców jest coraz więcej. Ta dysproporcja wymaga reakcji, stanowi wielkie wyzwanie dla współczesnego społeczeństwa. Jednakże kultura zysku z uporem ukazuje osoby starsze jako ciężar, „balast”, a więc trzeba ich odrzucić. Smutną rzeczą jest patrzenie na to, że odrzuca się osoby starsze. Papież zauważa, że również należy do tej grupy wiekowej, którą społeczeństwo chce odrzucić (por. Franciszek 2017a).

Brak zdrowia i niepełnosprawność nie są wystarczającym powodem, aby wykluczyć lub, co gorsza, usunąć osobę z życia społecznego. Faktem jest, że osoby starsze najbardziej dotkliwie cierpią nie z powodu osłabienia organizmu 
i wynikającej stąd niepełnosprawności, ale opuszczenia, wykluczenia i braku miłości. Papież zdaje sobie sprawę, że nie zawsze osoby starsze, dziadek, babcia, mają rodzinę, która może ich przyjąć. W tej sytuacji najlepszym rozwiązaniem są domy dla osób starszych, które powinny być naprawdę domami, a nie więzieniami! Domy dla osób starszych starców powinny być „płucami” człowieczeństwa, powinny być wręcz ,sanktuariami” człowieczeństwa, gdzie osoba starsza i słaba jest otoczona troską i pielęgnowana jak starszy brat lub siostra (por. Franciszek 2015).

Miejsce, jakie wyznacza się dziś ludziom starszym, w dużej mierze wiąże się z wartościami, jakie są uznawane przez daną społeczność. Dlatego też tam, gdzie ceni się doświadczenie i mądrość - ludzie starsi otaczani są szacunkiem i życzliwością. Natomiast w społeczeństwie, które gloryfikuje młodość, wydajność i użyteczność - ludzie starsi bywają spychani na margines życia społecznego i traktuje się ich jak zbędny balast ${ }^{4}$. Ich długowieczność nie jest zawsze postrzegana jako Boży dar, ale czasami wręcz jako ciężar trudny do zniesienia, zwłaszcza gdy zdrowie znacznie podupada. Taka mentalność jest nie do zaakceptowania. Papież podkreśla naciskiem, że „naszym obowiązkiem jest wytworzenie «przeciwciał»w obronie przed takim sposobem traktowania osób starszych czy niepełnosprawnych, jakby ich życie przestało być godne tego, by je przeżywać. To jest grzech, to jest ciężki grzech społeczny" (Franciszek 2019). Papież, zwracając się do wiernych zgromadzonych na placu św. Piotra, mówił: „Społeczeństwo stara się nas odrzucić, ale Pan nas nigdy nie odrzuca, wzywa nas, byśmy podążali za Nim w każdym wieku" (Franciszek 2017). Zadaniem Kościoła jest rzucanie wyzwania tendencji do spychania ludzi starszych na margines. Dziś nie ma się odwagi powiedzieć tego otwarcie, ale w tym, co się robi, jest coś niegodziwego. Ludzkość chce się pozbyć coraz większego strachu przed słabością i niedołężnością. Jednakże, postępując w ten sposób, zwiększa się w osobach starszych lęk, że są z trudem znoszone i opuszczone (por. Franciszek 2017). Problematyka starzenia się i niepełnosprawności jest niezwykle aktualna i bardzo leży na sercu Kościołowi. Niestety w wielu społeczeństwach obserwuje się bezwzględne panowanie logiki ekonomicznej, która wyklucza, a niekiedy zabija, i której ofiarami pada dziś bardzo wielu ludzi, poczynając od osób w podeszłym wieku. Papież

${ }^{4} \mathrm{~W}$ Europie pojęcie wykluczenia społecznego zostało użyte po raz pierwszy w latach 70 . XX wieku we Francji i było związane z polityką tego kraju. W latach 90. minionego wieku polityka społeczna skupiała się na ,walce” i ,likwidacji” wykluczenia społecznego. Osoby wykluczone były opisywane jako niewiele znacząca warstwa społeczna, która składała się z jednostek, prowadzących pasożytniczy tryb życia, wykolejonych, naruszających przepisy prawa i normy współżycia społecznego. Obecnie pojęcie wykluczenia związane jest z ograniczeniem dostępu do praw, zasobów i możliwości, do których mają dostęp inni członkowie społeczeństwa (Madeja-Bień i Gamian-Wilk 2017, 46). 
uczy, że daliśmy początek kulturze „odrzucenia”, a którą wręcz się promuje. „Wykluczeni nie tyle są «wyzyskiwani», ale są odrzuceni, są «niepotrzebnymi resztkami»" (Franciszek 2014, 53).

Wraz z odrzuceniem społecznym wiąże się ściśle zagadnienie samotności i osamotnienia (Dyczewski 2013, 857). Jest to problem ogólnoludzki, szczególnie dotkliwie odczuwany w czasach szybkiego rozwoju cywilizacyjnego, rozpadu więzi, koncentracji na sobie, indywidualnym sukcesie itp. O ile samotność najczęściej ma charakter obiektywny i oznacza sytuację, gdy ktoś np. mieszka sam czy jego bliscy nie żyją albo są daleko, o tyle osamotnienie jest odczuciem subiektywnym. Dotyczy negatywnej, niechcianej rozbieżności między własnymi oczekiwaniami a stanem faktycznym $w$ zakresie relacji z innymi ludźmi i towarzyszą mu negatywne emocje, czasem manifestujące się zaburzeniami w funkcjonowaniu. Samotność niejednokrotnie jest wybierana dobrowolnie i przypisuje się jej pozytywne strony - osamotnienie natomiast nigdy nie jest stanem pożądanym.

O alienacji (wyobcowaniu) z kolei mówi się najczęściej, że jest efektem rozpadu więzi społecznych. Częstym powodem, dla którego ludzie starsi są odsuwani w społeczeństwie na „boczny tor”, jest ich „inność”, która z kolei prowadzić może do stygmatyzacji. Mechanizm odrzucania czy obojętności w większości przypadków jest ten sam, natomiast specyfika doświadczenia osoby cierpiącej z powodu izolacji społecznej zawsze ma charakter indywidualny.

Franciszek, pisząc o samotności ludzi starszych, wskazuje m.in. na pewną niekonsekwencję w życiu politycznym: z jednej strony akcentuje się godność osoby ludzkiej i prawa człowieka, a z drugiej - okazuje się, że owe prawa nie dotyczą wszystkich i tracą swoją uniwersalność, gdy odnoszą się do życia osób starszych, potrzebujących pomocy. Powszechnie głoszone są poglądy podkreśla - że starość to rzeczywistość niechciana, to „zło konieczne”, które czyni człowieka nieproduktywnym i nieprzydatnym, a ludzie starzy są traktowani jako „balast społeczny”. W konsekwencji doświadczają odrzucenia bądź są spychani na margines i doświadczają samotności. Papież stwierdza z mocą, że odrzucanie osób starszych, pozostawianie ich samym sobie, jest prawdziwą ukrytą eutanazją (Franciszek 2015).

Ojciec święty ukazuje, że do samotności ludzi starszych przyczyniają się rozpowszechniane stereotypy, wedle których o wartości człowieka stanowi młodość, wydajność, fizyczna sprawność i pełnia zdrowia. Natomiast ludzie $\mathrm{w}$ podeszłym wieku, z ograniczonymi już siłami fizycznymi, wymagający pomocy ze strony drugich, stają się swego rodzaju przeszkodą. Na takim tle społecznym starość ukazywana jest jako czas pozbawiony wartości (Lewicka, 2019, 103). Ludzie starzy czują się niepotrzebni i widzą bezsens swojego życia. Zamykają się w sobie i w samotności podejmują trud radzenia sobie 
z problemami wieku, jakimi są: ciężar cierpienia związany z chorobą, ubytek sił, upokorzenie z powodu zależności od innych, poczucie bycia ciężarem dla najbliższych, nadchodząca śmierć, niezrozumienie ze strony innych, konflikt pokoleń oraz niepewność ekonomiczna. Papież wspomina, że już podczas swej posługi w Buenos Aires zetknął się z bliska z tą rzeczywistością i związanymi z nią problemami. „Osoby starsze są opuszczone, i to nie tylko w sensie niedostatku materialnego. Są opuszczone ze względu na egoistyczną niezdolność do zaakceptowania ich ograniczeń, które odzwierciedlają nasze ograniczenia, ze względu na liczne trudności, które muszą dziś pokonywać, by przeżyć w cywilizacji, która nie daje im możliwości uczestnictwa, wyrażenia swojego zdania ani bycia punktem odniesienia, zgodnie z konsumpcjonistycznym modelem, który zakłada, że «tylko młodzi mogą być użyteczni i korzystać z życia»»" (Franciszek 2017).

Kolejnym źródłem samotności ludzi starszych, na które zwraca uwagę papież, jest kryzys rodziny, polegający m.in. na tym, że osoby starsze traktowane są jako swego rodzaju zawada. Franciszek naucza, że spychanie ludzi starszych na margines życia rodzinnego jest niedopuszczalne chociażby ze względu na wdzięczność, jaka należy się im za trudy całego życia. W adhortacji apostolskiej Amoris laetitia dowodzi, że na osoby najstarsze zawsze powinno się ,patrzeć z szacunkiem” (Franciszek 2016a, 88). To im przecież rodziny zawdzięczają własną egzystencję, wychowanie, utrzymanie, a to wszystko często dokonywane było za cenę ciężkiej pracy i wielu cierpień. Osoby te nie mogą być traktowane jako niepotrzebne. Nawet jeśli czasem brak im sił do wykonania najprostszych czynności, mają jednak doświadczenie życiowe i mądrość, których często brak młodym (Franciszek 2016, 88).

W powiązaniu z powszechnie szerzącym się indywidualizmem dostrzega się coraz mniej przejawów solidarności międzyludzkiej. Ten zanik poczucia solidarności powoduje, że ludzie czują się bardziej osamotnieni, pozostawieni samym sobie, pozbawieni uczuciowego oparcia. Często choroba, opuszczenie przez najbliższych i świadomość nadchodzącej śmierci wywołują u ludzi starszych strach przed przyszłością i chęć zakończenia swojego życia.

Papież krytycznie odnosi się do działań niektórych mediów propagujących „kulturę śmierci”, która rodzi wśród ludzi starszych i chorych poczucie odrzucenia. Nazywa takie zachowania mediów marginalizacją społeczną i kulturową ludzi starszych i chorych. Franciszek podkreśla, że wiąże się z tym zanik solidarności społeczeństwa, a nawet „ekspansja kultury antysolidarystycznej”. Niepokojącą oznaką tego jest wewnętrzna pustka dręcząca wielu ludzi i utrata sensu życia (Franciszek 2014, 75).

Należy budować społeczeństwo bardziej gościnne, bardziej ludzkie, bardziej otwarte na wszystkich, które nie potrzebuje wyrzucać tego, kto jest słaby w ciele i na umyśle, wręcz przeciwnie społeczeństwo, które mierzy swoje 
„tempo”, zwracając uwagę na te osoby. W końcu papież dodaje: „Naród, który nie troszczy się o dziadków i nie traktuje ich dobrze, jest narodem niemającym przyszłości” (Franciszek 2015).

\section{Wartość starości}

Centralną myślą w nauczaniu Franciszka na temat ludzi starszych jest teza, że starość jest wartością, jest darem Bożym i duchowym bogactwem dla człowieka, dla rodziny i społeczności (Franciszek 2019). Podczas międzynarodowego kongresu poświęconego duszpasterstwu osób w podeszłym wieku papież stwierdził: „«Bogactwo lat» to bogactwo osób, każdej poszczególnej osoby, która ma za sobą wiele lat życia, doświadczeń i historii. Jest to cenny skarb, przybierający formę drogi życia każdego mężczyzny i każdej kobiety, niezależnie od ich korzeni, ich pochodzenia, ich warunków ekonomicznych czy społecznych. Bowiem życie to dar, a kiedy jest długie, stanowi przywilej dla nich samych i dla innych. Zawsze, zawsze tak jest" (Franciszek 2020).

Papież nieustannie podkreśla, że Kościół patrzy na osoby w podeszłym wieku z miłością, wdzięcznością i wielkim poważaniem. Osoby w podeszłym wieku są istotną częścią wspólnoty chrześcijańskiej i społeczeństwa (por. Franciszek 2017a). Wielokrotnie wyjaśnia, że wrażliwość na osoby starsze jest istotną cechą cywilizacji (por. Franciszek 2017). Z głębokim uznaniem i wdzięcznością wspomina swoją babcię Rosę, która była najważniejszą kobietą jego życia, to ona nauczyła go modlitwy i przekazała żywą wiarę (Lewicka 2019, 106).

Rzeczą konieczną jest uwrażliwianie współczesnych rodzin i całego społeczeństwa na skarb i bogactwo, jakie jest w starszych osobach. To one bowiem uczą mądrości życiowej. Czynić to należy w tym celu, by społeczeństwo umiało w pełni docenić ludzi starych, którzy słusznie są darzeni szacunkiem jako ,żywe biblioteki” mądrości, jako strażnicy bezcennego dziedzictwa ludzkiego i duchowego. W czasie spotkania z ludźmi starszymi i niepełnosprawnymi w Domu Starców w Turynie w 2015 roku ojciec święty mówił wprost: „Wśród ofiar kultury odrzucenia chciałbym tutaj wspomnieć szczególnie osoby starsze, których wiele zostało przyjętych w tym domu - osoby starsze, które są pamięcią i mądrością narodów" (Franciszek 2019).

Starość jest swoistym ,znakiem czasu”. Jeśli zostanie on właściwie odczytany, może dopomóc współczesnemu człowiekowi w odnalezieniu sensu życia, który to sens wykracza poza doczesność. Oznacza to, że obecność starszych może wzbogacić proces humanizacji społeczeństwa i kultury. Świat potrzebuje takiej mądrości i doświadczenia, aby zbudować przyszłość, która jeszcze bardziej będzie szanować prawa wszystkich. W związku z tym jeste- 
śmy wezwani do budowania społeczeństwa bardziej otwartego, bardziej ludzkiego, gdzie nikt nie jest wykluczony i odrzucony. Starość może być czasem obfitego dawania i dialogu (Franciszek 2020a). Choć, co prawda, w wymiarze fizycznym osoby w podeszłym wieku zazwyczaj potrzebują pomocy, to jednak nawet one mogą być oparciem dla młodych, którzy stawiają pierwsze kroki w życiu i szukają swojej drogi. Ich bowiem „dojrzałość i mądrość, gromadzone na przestrzeni lat, mogą pomóc najmłodszym, wspierając ich na drodze rozwoju i otwierania się na przyszłość, w poszukiwaniu własnej drogi” (Franciszek 2017a).

Właściwie przeżywana starość niesie ze sobą istotne wartości, bardzo potrzebne w życiu rodzinnym i społecznym. Do nich należy np. bezinteresowność. „Niemało jest osób starszych, które wielkodusznie poświęcają swój czas i talenty, jakimi obdarzył je Bóg, otwierając się na pomoc i wsparcie dla innych. Myślę o tych, które w parafiach z gotowością pełnią naprawdę cenną posługę: niektóre z nich zajmują się wyglądem domu Pańskiego, inne są katechetami, animatorami liturgii, świadkami miłosierdzia" (Franciszek 2017a). W obecnej kulturze wartość człowieka i jego czynów mierzy się kryteriami skuteczności i użyteczności. Tymczasem człowiek starszy bardziej gotowy jest do służby i postawy altruistycznej, przez co może wspomagać społeczeństwo w przełamywaniu barier obojętności i znieczulenia.

Obok bezinteresowności starszy człowiek w życie społeczne wnosi swoje bogate doświadczenie. W erze rozwoju nauki i techniki doświadczenie pokoleń zdaje się nie liczyć. Tymczasem człowiekowi nie wystarcza sama wiedza, potrzebna jest mądrość. To ona pozwala widzieć życie ludzkie bardziej całościowo i dać odpowiedź na fundamentalne pytanie dotyczące powołania, godności i przeznaczenia człowieka (Franciszek 2017a). Duchowe, moralne i religijne wartości, jakimi żyją ludzie starsi, stanowią niezastąpione źródła równowagi społeczeństwa, rodzin i jednostek. Rodzą one takie postawy jak: poczucie odpowiedzialności, przyjaźń, roztropność, cierpliwość, mądrość, duchową głębię, szacunek dla przyrody i postawę pokojowego rozwiązywania konfliktów. I w tym znaczeniu są one skarbcem mądrości dla całego społeczeństwa (Franciszek 2013, 83).

Starość jest ukoronowaniem poprzednich etapów życia. Niesie ze sobą plon tego, czego się człowiek nauczył i co przeżył. Ludzie w podeszłym wieku są niezwykle cenni dla rodziny i społeczeństwa. To oni są strażnikami pamięci zbiorowej. Oni pomagają mądrzej patrzeć na ziemskie wydarzenia, ponieważ dzięki życiowemu doświadczeniu zyskali wiedzę i dojrzałość. Mają szczególny tytuł, aby być wyrazicielami wspólnych ideałów i wartości, które są podstawą i regułą życia społecznego.

Ludzie starsi mogą być i są czynnikiem równowagi we współżyciu społecznym, które powinno rozwijać się nie na drodze rujnujących doświadczeń, 
ale na drodze mądrych i stopniowych przekształceń. Jest to możliwe tylko przy zaangażowaniu osób starszych i doświadczonych. Dzięki mądrości, jaką zdobyły w ciągu lat życia małżeńskiego, są dla swoich dzieci oparciem, a dla wnuków świadectwem trwałości rodziny, a często także pierwszymi osobami, które mówią im o Bogu i o Chrystusie.

Dialog i bliska więź między pokoleniami to bardzo ważne aspekty życia rodzinnego (Franciszek 2013, 83). To dzięki ludziom starszym nawiązywana jest więź międzypokoleniowa w rodzinie (Bołoz 1998, 87).

Szczególnie ważną rolę osoby starsze mogą odgrywać, przekazując swym dzieciom i wnukom wartości kulturowe i wzory życia. Utrzymując więź z członkami rodziny, przekazują określone wartości duchowe i postawy, które uważają za dobre, a które służą młodym w budowaniu przyszłego życia rodzinnego, kształtowaniu właściwego stosunku do innych ludzi, uczestnictwa w życiu społecznym. Ten przekaz wartości kulturowych ma ogromne znaczenie w prawidłowym przebiegu procesu socjalizacji ludzi młodych. $Z$ transmisją wartości kulturowych łączy się wychowanie młodego pokolenia do miłości ojczyzny dzięki przekazaniu mu narodowej tradycji i historii.

Obok dziedzictwa kulturowego ludzie starsi mogą przekazywać wartości religijno-moralne. Franciszek podkreśla: „Popatrzmy na Benedykta XVI, który postanowił spędzić ostatni etap swego życia na modlitwie i słuchaniu Boga, jakie to piękne" (Franciszek 2020c).

Często w przypadku niewierzących i niepraktykujących rodziców ich dzieci - dzięki dobrym kontaktom z dziadkami - deklarują swą wiarę w Boga i przystępują do sakramentów świętych. Człowiek starszy jest w stanie ubogacić świat modlitwą i wiarą. Franciszek zachęca ludzi starszych, by byli ,poetami modlitwy" (Franciszek 2020c). Mają oni bowiem wyjątkowe zdolności ewangelizowania, zwłaszcza w tych miejscach, gdzie thumione są swobody obywatelskie czy religijne. Odnosi się to szczególnie do krajów ateistycznych, gdzie dzięki dziadkom i babciom, którzy odważnie uczyli swoje wnuki prawd wiary, pokolenie średnie jest wierzące.

Człowiek starszy zwykle objawia większą religijność. Religia pomaga mu pełniej wykorzystać wartości wcześniej nagromadzone, pozwala łatwiej znosić dolegliwości i cierpienia, głębiej i twórczo przeżywać stan samotności i przez to go przezwyciężać. Pomaga też odnaleźć sens własnego życia, a także zaakceptować śmierć i widzieć w niej swoistą wartość. To budzi i utrwala postawę życiowego optymizmu, wzmacnia poczucie własnej wartości i godności. Nawet ludzie obojętni religijnie często na starość zbliżają się do wiary, lepiej ją rozumieją i czują jej potrzebę. Dzięki temu naturalne zadania starości, które wyrażają się w umacnianiu porządku moralnego i rozumnej opiece nad młodzieżą, są w swej istocie działaniami, które służą realizacji królestwa Bożego. „Starość jest czasem łaski, w którym Pan odnawia swoje wezwanie do prze- 
chowywania i przekazywania wiary, do modlitwy, szczególnie wstawienniczej, oraz do bycia obok tych, którzy są w potrzebie. Osoby starsze, dziadkowie mają wyjątkową zdolność do wychwytywania trudnych spraw. I kiedy modlą się w tych sprawach, ich modlitwa jest silna i skuteczna" (Franciszek 2015).

Ludziom starszym nie wolno popadać w pesymizm. Trzeba prosić Boga o to, by na starość nie stać się zgorzkniałymi i kwaśnymi jak ocet i by nie zatruwać innym życia swoim ciągłym narzekaniem. Pielęgnowanie przez całe życie wdzięczności wobec Boga i ludzi może nas uchronić od smutku, pesymizmu i zgorzknienia w latach starości. Procesu biologicznego starzenia nie da się powstrzymać. Można jednak przeszkodzić w pojawianiu się psychicznych oznak starzenia się. Papież życzy, by starsi byli jak dobre wino, które $\mathrm{z}$ upływem czasu staje się coraz lepsze. Złe wino zaś przekształca się w ocet. Chodzi o to, by starzeć się jak dobre wino, mądrze, aby móc przekazywać mądrość. Sam mówi o sobie: „Wchodzę w wiek podeszły i się temu nie opieram. Przygotowuję się do tego, a nie chce być winem kwaśnym, tylko dojrzałym. Zgorzknienie starca jest czymś najgorszym, to droga, z której nie ma powrotu" (Franciszek 2016). Starsi muszą mieć świadomość, że są potrzebni. Toteż nic dziwnego, że papież tak mocno podkreśla: „Starość - to nie jest moment, by przestać wiosłować i się wycofać” (Franciszek 2016).

\section{Solidarność z osobami starszymi}

Z nauczania Franciszka wynika, że starość, mając specyficzną wartość, jawi się jako moralne zadanie. Najpierw jest to zadanie dla samych ludzi starszych. Lata starości należy przeżywać w postawie ufnego zawierzenia Bogu. Ten czas trzeba twórczo spożytkować, dążąc do pogłębienia życia duchowego przez usilniejszą modlitwę i gorliwą służbę braciom w miłości. Okres starości stanowi też konkretne wyzwanie moralne dla rodziny, instytucji społecznych i Kościoła (Bartoszek 2005, 507).

Papież, apelując o solidarność z ludźmi starszymi, wskazuje, że pierwszą wspólnotą, która winna wspierać osoby starsze, jest rodzina. W przemówieniu do zgromadzenia ogólnego Papieskiej Akademii „Pro Vita” stwierdza: „Rodzina jest nauczycielką otwartości i solidarności” (Franciszek 2020d). To w niej wychowanie w istotny sposób opiera się na relacjach solidarności. Rodzina uczy, jak nie popaść w indywidualizm, uczy też zachowywania równowagi między ja a my.

Franciszek dowodzi, że „to w niej «zaopiekowanie się» staje się fundamentem egzystencji ludzkiej i postawą moralną, którą należy upowszechniać poprzez wartości zaangażowania i solidarności”. Stwierdza także, że „świadectwo rodziny nabiera decydującego znaczenia wobec całego społeczeństwa 
dla potwierdzenia znaczenia osoby w podeszłym wieku jako podmiotu wspólnoty ludzkiej" (Franciszek 2020d).

Rodzina jest najbardziej godnym miejscem starzenia. To ona najlepiej zapewnia człowiekowi staremu poczucie bezpieczeństwa. Można się w niej nauczyć, że utrata zdrowia nie jest powodem do dyskryminowania niektórych istnień ludzkich. Starość często jest bowiem połączona z chorobami i wielkim cierpieniem. Poprawna i głęboka więź rodzinna pomaga poszczególnym członkom rodziny nie tylko przetrzymać okres cierpienia, ale ubogacić się osobowo. Pomoc rodziny jest konieczna szczególnie wtedy, gdy leczenie jest związane z dużym wysiłkiem organizacyjnym i jest kosztowne. Związek z rodziną ogromnie ułatwia pokonanie choroby nawet w tych społeczeństwach, w których opieka lekarska jest dobrze zorganizowana. Wzmożona opieka ze strony krewnych, ich gesty życzliwości i miłości mogą umocnić chorego i przekonać go, że jest im potrzebny. Trudno przecenić pozytywny wpływ tej troskliwości i miłości na psychikę chorego (Reroń 2000, 571).

W rodzinie opiekę nad starszymi powinny sprawować dzieci. Zobowiązane są do tego przez czwarte przykazanie: „Czcij ojca i matkę swoją”. Czcić ludzi starych znaczy spełniać trojaką powinność wobec nich: akceptować ich obecność, pomagać im i doceniać ich zalety, przy czym relacja między rodziną a ludźmi starszymi winna być postrzegana zawsze jako wymiana darów (Szafulski 1999, 114). Według Franciszka istotną cechą cywilizacji prawdziwej, ludzkiej, jest szacunek do ludzi starszych, dzięki czemu mogą oni czuć się mimo słabnących sił - żywą częścią społeczeństwa (Franciszek 2017).

Wyrazem solidarności ze starszymi jest umożliwienie im rodzinnej bliskości. Ludzie starsi potrzebują kontaktu ze swoimi dziećmi i wnukami. Pragną oni partycypować w normalnym życiu. Doznają w ten sposób wsparcia psychicznego i poczucia bezpieczeństwa. Pragnienie ludzi starszych pozostawania w rodzinie do końca swoich dni staje się tym silniejsze, im silniejsza w danym społeczeństwie jest tendencja do stosowania eutanazji. Pozostawanie w kochającej rodzinie daje im większą szansę na naturalną śmierć.

Franciszek wskazuje także na pomocniczą, w stosunku do rodziny, rolę instytucji opieki socjalnej i podkreśla, że winny one kierować się nie tylko kryteriami sprawności organizacyjnej, ale dobrocią i wrażliwością. W czasie spotkania ze starszymi w Małym Domu Opatrzności Bożej w Turynie papież wskazał na postać jego założyciela św. Józefa Cottolengo. Od niego właśnie można nauczyć się innego spojrzenia na życie i osobę ludzką. „Cottolengo długo rozważał ewangeliczny opis ostatecznego sądu Jezusa, znajdujący się w rozdziale 25. Ewangelii św. Mateusza. Nie pozostał głuchy na wezwanie Jezusa, który prosi, aby Go nakarmić, napoić, przyodziać i odwiedzać. Przynaglany miłością Chrystusa, rozpoczął dzieło charytatywne, w którym Słowo Boże ukazało całą swoją owocność. Możemy się od niego uczyć konkretnego 
wyrażania ewangelicznej miłości, aby wielu ubogich i chorych mogło znaleźć «dom», żyć jak w rodzinie, poczuć, że należą do wspólnoty, że nie są wykluczani i jedynie tolerowani” (Franciszek 2019).

Przeżywanie starości wiąże się często z potrzebą opieki medycznej i pielęgniarskiej. Prowadzi to niestety niekiedy do napięć społecznych związanych m.in. z kosztami takiej opieki. Coraz częściej pojawia się tendencja, aby przyjmować określony wiek jako kryterium określające celowość nakładów finansowych na rzecz osób starszych. Jednakże, jak przypomina Kościół, nawet człowiek starszy, który jest poważnie lub nieuleczalnie chory i nie może utrzymywać normalnych relacji z innymi, nie traci w najmniejszej mierze swojej godności. Toteż państwo oraz instytucje powołane dla dobra ludzi starszych winny $\mathrm{w}$ ramach solidarności z nimi zapewnić im takie formy opieki społecznej i zdrowotnej, aby mogli oni żyć w sposób godny, sprawiedliwy i wolny.

We współczesnej medycynie coraz większe znaczenie zyskuje opieka paliatywna nad chorymi w starszym wieku. Opieka ta pozwala choremu na godne spędzenie ostatniego okresu życia - możliwie jak najdłużej pośród rodziny. Różne formy holistycznej opieki paliatywnej winny być ciągłe i ofiarowane choremu wszędzie tam, gdzie on przebywa. Opieka domowa - najbardziej naturalna i bliska choremu, który chciałby jak najdłużej przebywać w gronie osób bliskich - jest najtańszą formą opieki. Opieka stacjonarna służy tym chorym, których dokuczliwe objawy trudno opanować w domu, pomaga odpocząć strudzonej rodzinie, a także przeznaczona jest dla chorych zupełnie samotnych.

Samotność, jako wyczuwalny brak obecności, i to nie tylko fizycznej, ale również emocjonalnej, w starości powinna - w nauczaniu papieża - rodzić czyny miłości, wyrażające się w służbie wolontariatu, aby wspierać rodziny osób starszych i chorych. Kościół traktuje wolontariat jako swoisty fenomen obecnych czasów. Przeciwstawiając się egoizmowi i przemocy w obecnym świecie, staje się on antidotum na kryzys wartości. Chrześcijański wolontariat jest świadectwem miłości braterskiej i wierności Ewangelii i jako taki ma wpływ na przyszłość ludzkości. Franciszek podkreśla ponadto, że „wolontariat to działalność, która jest dobra zarówno dla tych, którzy otrzymują, jak i tych, którzy się angażują. Praca na rzecz drugich jest bowiem w stanie przezwyciężać poczucie samotności, polepsza relacje i samopoczucie. Innymi słowy, zaangażowanie w wolontariat wspiera to, co bywa nazywane «aktywnym starzeniem się», polepszając jakość życia” (Franciszek 2020a).

Papież częstokroć dowodzi, że społeczeństwa winny zawsze wspierać to dobro, które niesie ze sobą starość. Ma to szczególne znaczenie w odniesieniu do ludzi młodych. Przyszłość danego narodu bowiem zakłada dialog i spotkanie między starszymi a młodymi, aby tworzyć społeczeństwa bardziej sprawiedliwe, piękne, bardziej chrześcijańskie. „Instytucje i różne środowiska społeczne mogą uczynić bardzo wiele, by pomóc osobom starszym lepiej 
wykorzystywać swoje umiejętności, by ułatwiać im aktywne uczestniczenie, a przede wszystkim, aby ich godność osób była zawsze szanowana i doceniana. Aby to urzeczywistnić, trzeba sprzeciwiać się szkodliwej kulturze odrzucania, która spycha na margines osoby starsze, uważając je za bezproduktywne. Odpowiedzialni za życie publiczne, środowiska kulturalne, edukacyjne i religijne, a także wszyscy ludzie dobrej woli powołani są do tego, by się angażowali na rzecz budowania społeczeństwa coraz bardziej przyjaznego i inkluzyjnego" (Franciszek 2017a).

Ojciec święty, zwracając się do polityków i działaczy społecznych, podkreśla, że ludzie starzy powinni być włączani w życie społeczne na zasadach równorzędnych partnerów, są bowiem jego integralną częścią. „Słabi jesteśmy po trosze wszyscy, starsi. Niektórzy są jednak szczególnie słabi, liczni są samotni, dotknięci chorobą. Niektórzy są uzależnieni od koniecznych terapii i wrażliwości innych. Czy z tego powodu się wycofamy? Zostawimy ich na pastwę losu? Społeczeństwo bez bliskości, gdzie bezinteresowność i uczucia wolne od kalkulacji - również wśród obcych - zanikają, jest społeczeństwem przewrotnym. Kościól, wierny Słowu Bożemu, nie może tolerować takich zwyrodnień. Wspólnota chrześcijańska, w której bliskość i bezinteresowność nie byłyby uznawane za niezbędne, razem z nimi postradałaby swoją duszę. Tam, gdzie brakuje czci dla osób starszych, nie ma przyszłości dla młodych" (Franciszek 2017).

Nauczanie Kościoła katolickiego o starości jest niezmienne i wynika z nauki o godności osoby ludzkiej. Godność jest wewnętrznym, wrodzonym i naturalnym znamieniem człowieka, niezależnym od kontekstu społecznego i historycznego (Duda 2013, 71). Społeczeństwo ma obowiązek jej poszanowania i chronienia. Wszyscy ludzie mają tę samą naturę i to samo pochodzenie, cieszą się więc równą godnością. Franciszek nieustannie przypomina, że służba człowiekowi starszemu jest służbą życiu w godności. Nie godzi się on z odtrącaniem ludzi słabych, potrzebujących i starców. Ojciec święty wzywa do konkretnej postawy i domaga się służenia tym starszym, którzy wołają o pomoc, ale i tym, którzy ukrywają swoją ludzką biedę. „W tradycji Kościoła jest bagaż mądrości, która zawsze umacniała kulturę bycia blisko osób starszych, gotowość do pełnego miłości i solidarnego towarzyszenia w schyłkowym okresie życia. Tradycja ta jest zakorzeniona w Piśmie Świętym, o czym świadczą na przykład te słowa z Księgi Syracha: «Nie odsuwaj się od opowieści starców, albowiem i oni nauczyli się ich od swoich ojców; od nich i ty nauczysz się rozumu, by w czasie potrzeby dać odpowiedź» (Syr 8,9)" (Franciszek 2017).

Według ojca świętego starość stanowi wyzwanie do solidarności ze starszymi nie tylko dla rodziny i różnych instytucji świeckich, ale i dla Kościoła. Choroba, niepełnosprawność powodują, że ludzie starsi nie są samowystarczalni. Często wstydzą się nieustannie prosić o pomoc i wycofują się z życia 
codziennego, aby nikomu nie stwarzać problemów i nie być ciężarem. Dlatego papież uczy: „Wysłuchałem świadectw niektórych z was, mówiących o doświadczeniach wspólnych licznym osobom starszym i dziadkom. Ale jedno z nich było inne: świadectwo braci przybyłych z Karakoszu, którzy zbiegli przed okrutnym prześladowaniem. Im wszyscy razem powiedzmy specjalne «dzięki!» To wspaniałe, że przybyliście tu dzisiaj: to jest dar dla Kościoła. A my ofiarujemy wam naszą bliskość, naszą modlitwę i konkretną pomoc. Przemoc względem osób starszych jest nieludzka, podobnie jak przemoc względem dzieci. Ale Bóg was nie opuszcza, jest z wami! Z Jego pomocą jesteście i wciąż będziecie pamięcią dla waszego ludu; a także dla nas, dla wielkiej rodziny Kościoła” (Franciszek 2015).

\section{Nowy wymiar pracy duszpasterskiej z osobami starszymi}

Duszpasterstwo ludzi starszych nie jest czymś nowym dla Kościoła. Niemniej jednak współczesne uwarunkowania, z którymi spotyka się człowiek starszy, muszą być na nowo przeanalizowane. Dotyczą one przede wszystkim przeobrażeń społeczno-kulturowych społeczeństwa. Czujność Kościoła oraz jego działalność zmierzająca do stałego przekazywania orędzia Chrystusowego nie tylko popiera aktywności już wypracowane, ale jednoznacznie mobilizuje do nowszych sposobów apostołowania, bardziej odpowiadających dzisiejszemu człowiekowi.

Warto zwrócić uwagę na to, że jednym z najbardziej charakterystycznych terminów, którym posługuje się papież, jest „nawrócenie duszpasterskie”. Niewątpliwie na potrzebę pewnej zmiany w stylu prowadzenia duszpasterstwa starszych i duszpasterstwa w ogóle, wpłynęło doświadczenie Kościoła, z jakiego wyszedł Franciszek - Kościoła w Ameryce Łacińskiej. Już w pierwszej adhortacji Evangelii gaudium można znaleźć bezpośrednie odniesienie się papieża do tego faktu. Franciszek przypomina, że troska o głoszenie Ewangelii wszystkim tym, którzy stoją z dala od Chrystusa, jest podstawowym zadaniem Kościoła. Biskupi Ameryki Południowej w nawiązaniu do tego wyzwania zdecydowali: „Nie możemy dłużej pozostawać w spokoju, w biernym oczekiwaniu, w naszych kościołach i że trzeba koniecznie dokonać przejścia od duszpasterstwa zwykłego zachowywania stanu rzeczy do duszpasterstwa zdecydowanie misyjnego" (Franciszek 2014, 15). W tejże adhortacji ojciec święty określa Kościół jako „wspólnotę ewangelizującą” oraz jako ten, który jest „wyruszający w drogę” (Franciszek 2014, 15). Zachęca do tego, by nawrócenie duszpasterskie i misyjne stało się udziałem wszystkich wspólnot - całego Kościoła. Ta zachęta i wezwanie są podyktowane troską pasterza, który pragnie dobra powierzonej mu owczarni. 
Papież podejmuje próbę odpowiedzi na pytanie o kształt duszpasterstwa osób starszych w obecnym czasie. Według niego duszpasterstwo starszych, tak jak do tej pory je prowadzono, bardzo ucierpiało w zderzeniu ze zmianami społecznymi. W zwyczajnych strukturach starsi często nie znajdują odzewu na pojawiające się pytania, potrzeby i zranienia. Idąc za sugestiami Franciszka dotyczącymi duszpasterstwa seniorów, trzeba wskazać najpierw na tzw. ,apostolstwo ucha", które wyraża postawę cierpliwego i miłosiernego słuchania drugiego człowieka oraz ofiarowania mu swojego czasu.

W adhortacji Evangelii gaudium papież pisze, że starszym niełatwo cierpliwie słuchać, zrozumieć niepokoje i żądania ludzi młodych (Franciszek 2014, 105). Zwraca w ten sposób uwagę nie tylko na problemy związane z konfliktem pokoleń, ale na dostrzegany dziś ogólny problem komunikacji pomiędzy ludźmi. Obserwuje się przecież narastające obecnie zjawisko samotności człowieka, nawet tego, który przebywa wśród wielu ludzi. Liczne relacje współczesnego człowieka nierzadko są powierzchowne, rzeczowe i nie sięgają głębi człowieka.

Trzeba zatem dokonać przemiany w mentalności i w nastawieniu młodszego pokolenia wobec ludzi starych. Służy temu ukazana na podstawie biblijnej katechezy wizja starości, co może odsłonić problemy egzystencjalne osób starszych, które uwrażliwiałyby, przekonywały i pozwalały wykształcić pozytywną postawę wobec tych ludzi. „Boży plan zbawienia w istocie realizuje się także w ubóstwie ciał słabych, niepłodnych i pozbawionych mocy. Z obumarłego łona Sary i ze stuletniego ciała Abrahama zrodził się naród wybrany (por. Rz 4,18-20). Z Elżbiety i starego Zachariasza narodził się Jan Chrzciciel. Człowiek stary, również, kiedy jest słaby, może stać się narzędziem historii zbawienia" (Franciszek 2014, 105).

W rozmowie z Andreą Torniellim Franciszek wspomina o ,apostolstwie ucha". Mówi o tym w kontekście zamętu obecnych czasów, który polega na przekonaniu, że nie ma możliwości uwolnienia, przebaczenia, powrotu na dobrą drogę. Takie zagubienie popycha ludzi do poszukiwania wsparcia w magii, horoskopach, przepowiedniach dotyczących przyszłości, co można potraktować jako swego rodzaju kompensację egzystencjalnej pustki, charakteryzującej obecne czasy. Zdaniem papieża, ludzie szukają przede wszystkim kogoś, kto ich wysłucha i jest gotowy poświęcić swój czas, aby poznać ich dramaty i rozterki. To właśnie można nazwać ,,apostolstwem ucha”, które jest bardzo ważne nie tylko dla spowiedników, ale także dla wszystkich duszpasterzy (Franciszek 2016b, 36-39). Duszpasterstwo osób starszych wymaga poświęcenia swego czasu człowiekowi w podeszłym wieku, przebywania z nim, cierpliwego słuchania i rozmowy. Człowiek starszy chce w duszpasterzu spotkać autentycznego świadka i przewodnika na drodze do Boga. Takie działania wymagają cierpliwego rozeznawania razem ze starszym człowiekiem, czego 
oczekuje od niego Bóg, a także miłosiernego wsparcia w trudach realizacji woli Bożej.

Należy też, zdaniem Franciszka, zwrócić baczną uwagę na konieczność wypracowania właściwego języka w posłudze na rzecz starszych. W 2013 roku w Rio de Janeiro papież wypowiedział znamienne słowa: „Czasami tracimy tych, którzy nas nie rozumieją, bo oduczyliśmy się prostoty, czerpiąc z zewnątrz również pewną racjonalność obcą naszym ludziom. Rezygnując z języka prostoty, Kościół pozbawia się warunków, które umożliwiają «łowienie» Boga w głębokich wodach Jego tajemnicy” (Franciszek 2020e). Według papieża także w pracy ze starszymi ludźmi trzeba nauczyć się mówić zrozumiałym dla nich językiem (Franciszek 2014, 105). Trzeba przyznać, że sam Franciszek mówi językiem, który trafia do ludzi. W swoich homiliach używa obrazów i porównań z życia wziętych, unika trudnego teologicznego języka. Nie boi się odwoływać do swoich osobistych doświadczeń, chętnie przytacza historie, które go spotkały, i poruszające słowa ludzi, z którymi rozmawiał. Można powiedzieć, że papież Franciszek używa języka egzystencjalnego, bliskiego życiu i sprawom współczesnym.

Poszukiwanie zrozumiałego języka przepowiadania Ewangelii jest zadaniem trudnym, ale koniecznym w każdym czasie i przestrzeni (Fiałkowski 2016, 91). Jak bardzo skomplikowane jest to wyzwanie w stosunku do współczesnego człowieka, wskazuje choćby język, z którego korzysta się w mediach społecznościowych. Ogólnie mówiąc, charakteryzują go skrótowość, liczne uproszczenia, wykorzystywanie obrazów itp. Stawia to przed duszpasterzami zadanie poznawania starszych ludzi, poświęcania im odpowiedniej uwagi i czasu, rozmowy i wsłuchiwania się w ich oczekiwania.

Wysiłek dostosowania języka przepowiadania Dobrej Nowiny do obecnej mentalności starszych musi unikać uproszczenia i spłycenia - sztucznych i nieprzystających do powagi głoszonych treści (Leonowicz 1998, 50). Prowadzi to nie tylko do zubożenia przesłania i utraty świadomości obcowania z tajemnicą, ale także naraża na śmieszność spowodowaną nieudolnym kopiowaniem i naśladownictwem. Innym niebezpieczeństwem jest przekonanie o niemożliwości wyrażania ewangelicznego przesłania w nowej, uwspółcześnionej formie. Stąd tylko krok do niezrozumiałego żargonu, jakże odległego od głoszenia Mistrza z Nazaretu.

Kolejną inspiracją płynącą z nauczania papieża, na którą warto zwrócić uwagę $\mathrm{w}$ duszpasterstwie starszych, jest zadanie budowania środowiska chrześcijańskiego. Franciszek wspomina, że współczesne przemiany prowadzą ludzi, zwłaszcza starszych, do poszukiwania przynależności (Franciszek 2014, 105). Obserwuje się z jednej strony dużą niechęć i podejrzliwość wobec wszelkich instytucji, połączoną z upadkiem i kwestionowaniem autorytetów oraz szerzeniem się relatywizmu. $\mathrm{Z}$ drugiej zaś strony dostrzega się poszuki- 
wanie przynależności i niemal głód jasnych i precyzyjnych wskazań, pomagających w znoszeniu ciężaru życia, dokonywania wyborów i znajdowania odpowiedzi na odwieczne pytania, które zadaje sobie człowiek. W tym kontekście duszpasterstwo starszych winno podjąć wysiłek budowania środowiska chrześcijańskiego. Chodzi o tworzenie takiej przestrzeni, która zgromadzi ludzi, nie tylko podzielających tę samą wiarę w Boga, ale starających się nią odważnie dzielić, swobodnie o niej mówić, spotykających się równocześnie ze zrozumieniem ze strony innych. Każdy z wierzących, aby żyć autentycznie po chrześcijańsku, potrzebuje otoczenia, w którym wiara jest otwarcie akceptowana, w którym się o niej mówi i nią żyje.

Działalność i posłannictwo wspólnoty Kościoła dokonuje się w pewnych widzialnych strukturach. Takim podstawowym wymiarem obecności Kościoła jest parafia. Warto więc przypomnieć, że od początku istnienia Kościoła odgrywała ona fundamentalną rolę w życiu chrześcijan, a także w realizowaniu duszpasterstwa osób starszych opartego na głoszeniu wiary i sprawowaniu sakramentów. Papież podczas spotkania z biskupami polskimi przypomina: „Parafia jest ciągle aktualna! Musi pozostać: jest strukturą, której nie wolno nam wyrzucić przez okno. Jest domem ludu Bożego, tym domem, w którym on mieszka" (Franciszek 2016c).

Franciszek podkreśla, że potrzebne jest nawrócenie duszpasterskie. Posługa kapłańska wobec starszych nie powinna opierać się tylko na powtarzaniu utartych czynności duszpasterskich. Dzisiaj ujawnia się potrzeba różnorodnych propozycji duszpasterskich, które pozwoliłyby dotrzeć ze słowem Bożym i sakramentami do każdego w sposób odpowiadający jego sytuacji życiowej. Ważne jest, by parafia głosiła słowo w sposób jasny i zrozumiały dla współczesnego człowieka, a sprawowana Eucharystia rzeczywiście budowała wspólnotę. Toteż parafia powinna również - wobec problemu wykluczenia społecznego starszych oraz samotności - stanowić żywy znak obecności Chrystusa. Jej wyrazem powinno być budowanie braterskich relacji międzyludzkich. Przepowiadanie Ewangelii dokonuje się głównie poprzez świadectwo ludzi, którzy swoim postępowaniem uwiarygadniają to, co głoszą. Jeżeli ewangelizacja pozostaje w ścisłym związku z jakością relacji międzyludzkich, to parafia powinna być takim miejscem, które będzie sprzyjać budowaniu relacji między sobą.

Należy pamiętać, że tradycyjne struktury parafialne, aby mogły odpowiadać na potrzeby współczesności, powinny być coraz bardziej postrzegane w „kluczu misyjnym”. Franciszek podkreśla, że „parafia nie jest strukturą ułomną; właśnie dlatego, że ma wielką elastyczność, może przyjąć bardzo odrębne formy, wymagające otwarcia i misyjnej kreatywności ze strony duszpasterza i wspólnoty”. Zauważa on także, że ,wezwanie do rewizji i odnowy naszych parafii nie przyniosło jeszcze wystarczających owoców, aby były bliżej 
ludzi i stanowiły środowiska żywej komunii i uczestnictwa i ukierunkowały się całkowicie na misję" (Franciszek 2014, 28).

Papież uważa również, że proces odnowy parafii jest zadaniem, które domaga się dużej roztropności. Powinien przebiegać elastycznie i stopniowo. Wszelkie projekty zmian powinny uwzględniać życie i realia konkretnej wspólnoty. Jednocześnie należy pamiętać, że wszelkie podejmowane w tej materii działania nie mogą być działaniem samego duszpasterza, ale powinny być realizowane we współpracy z wiernymi.

Konkretnym wyrazem tego, że to cały Lud Boży jest podmiotem duszpasterstwa, jest parafialna rada duszpasterska. Może ona wnieść wiele ducha ewangelizacyjnego w życie wspólnoty parafialnej, pod warunkiem, że jej celem nie będzie jedynie organizacja kościelna, ale realizacja misyjnego zadania, by dotrzeć do wszystkich ludzi.

W duszpasterstwie seniorów należy, zdaniem Franciszka, zająć się pogłębianiem duchowości osób starszych. Pomoc duszpasterska w tej mierze nabiera obecnie coraz większego znaczenia. Wypływa to z następujących przyczyn: pogłębia się świadomość seniorów dotycząca sensu życia i przemijania oraz miejsca osób starszych w środowisku parafialnym. Zachodzi konieczność świadczenia posługi ludziom w podeszłym wieku dzięki oparciu się na rzeczywistości Bożej z uwzględnieniem nade wszystko modlitwy, czytania Pisma Świętego, posługi sakramentalnej oraz uczestniczenia, na ile to jest możliwe, w liturgicznej działalności Kościoła parafialnego. Podczas spotkania z uczestnikami międzynarodowego kongresu poświęconego duszpasterstwu osób w podeszłym wieku Franciszek stwierdził: „Z zainteresowaniem przyjąłem inicjatywę tego kongresu, który skupił uwagę na duszpasterstwie osób starszych i zapoczątkował refleksję nad skutkami pokaźnej obecności starców w naszych parafiach i w społeczeństwach. Proszę was, aby nie pozostała ona inicjatywą odosobnioną, ale żeby oznaczała początek drogi duszpasterskiego pogłębiania i rozeznania. Powinniśmy zmienić nasze przyzwyczajenia duszpasterskie, aby umieć odpowiedzieć na obecność tak licznych osób starszych w rodzinach i we wspólnotach" (Franciszek 2020). Papież nawołuje usilnie duszpasterzy do niestrudzonego głoszenia Ewangelii wszystkim osobom starszym: „Proszę was, nie szczędźcie sił w głoszeniu Ewangelii dziadkom i osobom starszym. Wychodźcie im na spotkanie z uśmiechem na twarzy i z Ewangelią w rękach. Wychodźcie na ulice waszych parafii i idźcie szukać osób starszych, które żyją same" (Franciszek 2020).

Należy podkreślić ponadto potrzebę podjęcia wysiłku na rzecz odważnego poszukiwania nowych dróg w duszpasterskiej pracy z ludźmi starszymi. Zdaniem Franciszka, zachodzi konieczność podjęcia przez Kościół nowych zadań wobec ludzi starych, co sugeruje i zaleca posoborowe rozumienie Ludu Bożego. Implikuje to konieczność dostrzeżenia i wykorzystania wielkiego po- 
tencjału ludzi świeckich. Papież uczy, że „kiedy myślimy o osobach starszych i o nich mówimy, tym bardziej w wymiarze duszpasterskim, powinniśmy się nauczyć używania czasowników w innych nieco czasach. Istnieje nie tylko przeszłość, jak gdyby dla osób starszych istniało jedynie życie, które mają za sobą, i zaśniedziałe archiwum. Nie. Pan może i chce zapisywać z nimi także nowe stronice, stronice świętości, służby, modlitwy. Dziś chciałbym wam powiedzieć, że również osoby starsze są teraźniejszością i jutrem Kościoła" (Franciszek 2020). Ponownie podkreślając konieczność wykorzystania przez duszpasterzy wielkiego potencjału ludzi świeckich, ojciec święty uczy: „Musimy się przyzwyczaić do włączania starszych w nasze perspektywy duszpasterskie i do traktowania ich, w sposób nieepizodyczny, jako jedną z życiowych części naszych wspólnot. Oni są nie tylko osobami, którym mamy pomagać i które mamy chronić, aby strzec ich życia, ale mogą także być uczestnikami duszpasterstwa ewangelizacyjnego, uprzywilejowanymi świadkami wiernej miłości Boga" (Franciszek 2020).

Świeccy katolicy trzeciego wieku są niezastąpionymi apostołami, szczególnie w dziedzinie budowania więzi rodzinnych, działalności charytatywnej, w zbawczym przeżywaniu cierpienia i modlitwie (Leonowicz 1998, 52). Wyzwaniem duszpasterskim jest troska o to, by seniorzy byli świadomi swoich zadań apostolskich w aktualnie przeżywanej fazie życia. Należy im przypominać, że czas ten nie może być stracony. Jego nadmiar stwarza wreszcie możliwość spokojnej refleksji nad najważniejszymi kwestiami życia, które wcześniej były pomijane z uwagi na sprawy bardziej naglące (por. Franciszek 2020).

Duszpasterstwo i zaangażowanie apostolskie seniorów domagają się obecnie większego uznania i wyraźniejszego dowartościowania ich w życiu Kościoła. Papież w adhortacji Evangelii gaudium przypomina wszystkim, że jako chrześcijanie ,jesteśmy powołani do troski o najbardziej kruchych mieszkańców ziemi” (Franciszek 2014, 209). Do nich obok dzieci niewątpliwie należą ludzie w podeszłym wieku. I chociaż na pozór nie przynosi to namacalnych i natychmiastowych korzyści - uczy papież Franciszek - to ,jest rzeczą nieodzowną, by być blisko nowych form ubóstwa i kruchości, w których jesteśmy wezwani do rozpoznania Chrystusa cierpiącego" (Franciszek 2014, 210). Ostatecznie seniorzy stanowią szansę dla pozostałych grup wiernych na rozpoznanie w nich ukrytego Chrystusa i okazanie Mu miłosierdzia (por. Łk 10,37).

Papież, doceniając wielki wysiłek kapłanów w pracy z osobami starszymi, dziękuje im za ich ofiarne zaangażowanie się. „Dziękuję wszystkim za to, że poświęcacie swoje duszpasterskie energie dziadkom i osobom w podeszłym wieku. Dobrze wiem, że wasze zaangażowanie i wasza refleksja wynikają z konkretnej przyjaźni z licznymi osobami starszymi. Mam nadzieję, że ta dzisiejsza wrażliwość nielicznych stanie się dziedzictwem całej wspólnoty 
kościelnej. Nie obawiajcie się, podejmujcie inicjatywy, pomagajcie waszym biskupom i waszym diecezjom w rozwijaniu posługi duszpasterskiej na rzecz osób starszych i z osobami starszymi. Nie zniechęcajcie się, idźcie naprzód!” (Franciszek 2020).

\section{Zakończenie}

Starość jest okresem życia następującym po wieku dojrzałym. W wymiarze biologicznym wiąże się z osłabieniem funkcji życiowych, a niekiedy także $\mathrm{z}$ chorobami i niedołęstwem. Funkcjom fizycznym towarzyszą często zmiany w psychice. W wymiarze społecznym oznacza zakończenie aktywności zawodowej, połączone czasami z osłabieniem więzi społecznych.

Problem starości Franciszek podejmuje w licznych przemówieniach kierowanych do osób starszych czy na spotkaniach z nimi w czasie swych pielgrzymek apostolskich. Papieżowi troska o ludzi starszych leży głęboko na sercu. Podkreśla on zdecydowanie, że szacunek wobec osób starszych jest tym potrzebniejszy, im bardziej we współczesnym świecie dochodzą do głosu tendencje, które - w imię mitu młodości i sprawności fizycznej, używając kryteriów wydajności i użyteczności - spychają na margines ludzi starych jako zbędny ciężar, zmuszają ich do życia w samotności, a nawet propagują eutanazję. Papież, stanowczo sprzeciwiając się różnym tendencjom zagrażającym osobom starszym, kieruje do współczesnych ludzi apel, by społeczeństwo odkryło na nowo solidarność między pokoleniami, odnalazło sens i znaczenie starości. Miarą cywilizacji jest ochrona, jaką społeczeństwo otacza swoje najsłabsze jednostki.

Franciszek w kontekście osób starszych mówi znaczeniu rodziny, o potrzebie zaangażowania w życiu społecznym, a także w życiu Kościoła. Zobowiązuje również duszpasterzy do jeszcze większego zaangażowania na rzecz ludzi starszych we wspólnotach Kościoła lokalnego.

\section{POPE FRANCIS ON THE PROBLEM OF ALIENATION AND LONELINESS OF ELDERLY PEOPLE}

\section{Abstract}

In the twenty-first century, the teaching of Pope Francis, and earlier John Paul II and Benedict XVI, by showing the role and place of the elderly in society, restores respect for them. The Pope wants the elderly to be respected and cared for with proper 
attention. It proves that the elderly are not only beneficiaries but also donors. Therefore, seniors are a valuable support for younger generations, because they bring wisdom and life experience, family and nation history, and are also witnesses of faith. According to the Pope, in the past, respect for the elderly was some kind of determinant of humanism. Undoubtedly, this should also be the case now, in order to positively testify to the quality of the 21 st century civilization. Thus, the elderly cannot be neglected and rejected.

Keywords: Francis; aging society; family; old age; grandparents; exclusion; alienation; the value of old age; solidarity with seniors; pastoral care for the elderly

Słowa kluczowe: Franciszek; starzenie się społeczeństwa; rodzina; starość; dziadkowie; wykluczenie; alienacja; wartość starości; solidarność z seniorami; duszpasterstwo osób starszych

\section{BIBLIOGRAFIA}

Franciszek. 2013. Solo l'amore ci puosalvare, Città del Vaticano: Libreria Editrice Vaticana.

Franciszek. 2014. Adhortacja apostolska „Evangelii gaudium”.

Franciszek. 2015. Pamięć o przeszłości i przyszłość. Przemówienie podczas spotkania z ludźmi starszymi na placu św. Piotra [28 IX 2014]. Dostęp: 28.08.2015. _i/ przemowienia/starsi2_28092014.html.

Franciszek. 2016a. Adhortacja apostolska „Amoris laetitia”.

Franciszek, 2016b. Miłosierdzie to imię Boga. Rozmowa z Andreq Torniellim. Tłumaczenie Joann Ganobis. Kraków: Wydawnictwo „Znak”.

Franciszek. 2016c. Przemówienie do biskupów polskich na Wawelu (27 VII 2016). Dostęp: 10.03.2021. https://www.gosc.pl/doc/3350842/.Pelny-zapis-rozmowy-papieza-z-polskimi-biskupami).

Franciszek. 2016. To nie jest moment, żeby przestać wiosłować. Katecheza podczas audiencji generalnej [11 III 2015], Dostęp 21.05.2016. https://www.rmf24.pl/fakty/swiat/news-franciszek-ostarosci-to-nie-jest-moment-zeby-przestac-wiosl,nId,1695882.

Franciszek. 2017a. Korzenie i pamięć społeczeństwa, Przemówienie podczas audiencji dla członków włoskich organizacji seniorów [15 X 2016]. Dostęp: 21.08.2017. pl/biblioteka/W/WP/franciszek_i/ przemowienia/seniorzy_15102016.html.

Franciszek. 2017. Ludzie starsi to my. Audiencja generalna [4 III 2015]. Dostęp: 3.07.2017.https:// opoka.org.pl/biblioteka/W/WP/franciszek_i/audiencje/ag_04032015.html.

Franciszek. 2019. Musimy się bronić przed kultura odrzucania. Spotkanie z ludźmi ubogimi, starymi i niepetnosprawnymi w Turynie [21 VI 2015]. Dostęp: 3.09.2019. ttps://opoka.org.pl/ biblioteka/W/WP/franciszek_i/przemowienia/turyn-ubodzy_21062015.html.

Franciszek. 2020a. Potrzebujemy waszej madrości $i$ doświadczenia. Przemówienie do członków Narodowego Stowarzyszenia Pracowników w Podeszłym Wieku [16 XII 2019]. Dostęp: 19.09.2020. https://archwwa. pl/wiadomosci/papiez-do-osob-starszych-potrzebujemy-waszejmadrosci-i-doswiadczenia/.

Franciszek. 2020b. Anioł Pański. Godzina Maryi. Rio de Janeiro - Balkon Domu Biskupów, 26 lipca 2013. Dostęp: 7.12.2020.http://www.vatican.va/content/francesco/pl/angelus/2013/documents/ papa-francescoangelus_20130726_gmg-rio.html. 
Franciszek. 2020c. My starcy. Dostęp: 7.12.2020. https://wiadomosci.onet.pl/swiat/papiezspoleczenstwo-chce-odrzucac-nas-ludzi-starszych/k1y4n9.

Franciszek. 2020d. Najcięższa choroba, na jaka sq narażone osoby starsze, jest opuszczenie. Przesłanie z okazji 20-lecia Papieskiej Akademii «Pro Vita» [19 II 2014]. Dostęp: 7.12.2020. https: //opoka.org.pl/biblioteka/W/WP/franciszek_i/przemowienia/starosc_19022014.Html.

Franciszek. 2020e. Przemówienie podczas spotkania z episkopatem Brazylii, Rio de Janeiro, 27.07.2013 r. Dostęp: 19.09.2020. https://w2.vatican.va/content/francesco/pl/ speeches/2013/ july/documents/papa-francesco20130727_gmg-episcopato-brasile.html.

Franciszek. 2020. Starość nie jest chorobą. Przemówienie do uczestników międzynarodowego kongresu poświęconego duszpasterstwu osób w podesztym wieku [31 I 2020]. Dostęp: 5.08.2020. https://www.osservatoreromano.va/pl/news/2020-03/starosc-nie-jest-choroba.html.

Bartoszek, Antoni. 2005. Starość (aspekt moralny). W: Encyklopedia nauczania moralnego, red. Janusz Nagórny i Krzysztof Jeżyna. 506-508. Radom: Polskie Wydawnictwo Encyklopedyczne.

Bołoz, Wojciech. 1998. Promocja osoby w rodzinie. Warszawa: Wydawnictwo Akademii Teologii Katolickiej, Oficyna Wydawniczo-Poligraficzna „Adam”.

Duda, Marian. 2013. Przemoc wobec ludzi starszych. Wybrane zagadnienia. Sosnowieckie Studia Teologiczne, 10, 57-72.

Dyczewski, Leon. 2013. Starość. Aspekt społeczny. W: Encyklopedia katolicka. 856-858. Lublin: Towarzystwo Naukowe Katolickiego Uniwersytetu Lubelskiego Jana Pawła II.

Fiałkowski, Marek. 2016. Papieża Franciszka inspiracje dla duszpasterstwa młodzieży. Polonia Sacra, 4, 87-99.

Halicka, Małgorzata. 1999. Wiek podeszły społeczeństwa: aspekty demograficzne. Ethos, 3, 138-148 .

Leonowicz, J. 1998. Duszpasterstwo ludzi starych. W: Duszpasterstwo specjalne, red. Ryszard Kamiński i Bogusław Drożdż. 39-54. Lublin: Atla 2.

Lewicka, Joanna. 2019. Wartość doświadczenia osób starszych dla rozwoju ludzi młodych w nauczaniu papieża Franciszka. Colloquia Theologica Ottoniana, 1, 99-113.

Madeja-Bień, Kamila et all. 2017. Wybrane skutki wykluczenia społecznego. Teraźniejszość - Człowiek-Edukacja, 4, 39-48.

Reroń, Tadeusz. 2000. Godność i misja człowieka starszego. W: Wręgu chrześcijańskiego orędzia moralnego, red. Marian Biskup i Tadeusz Reroń. 557-577. Wrocław: Papieski Wydział Teologiczny.

Szafulski, Andrzej. 1999. Godność człowieka w podeszłym wieku. Wrocławski Przegląd Teologicz$n y, 7,107-115$.

Ślipko, Tadeusz. 1999. Sens życia - sens starości w chrześcijaństwie. Ethos, 3, 15-18.

Zwoliński, Andrzej. 2005. Starość. W: Jan Paweł II. Encyklopedia nauczania społecznego, red. Andrzej Zwoliński. 484-493. Radom: Polskie Wydawnictwo Encyklopedyczne.

ANDRZEJ SzafulsKI - dr hab. kapłan archidiecezji wrocławskiej. Kierownik katedry teologii moralnej na PWT we Wrocławiu. Członek Komisji Bioetycznej przy Dolnośląskiej Izbie Lekarskiej we Wrocławiu i „Association of Bioethicists in Central Europe - BCE. Autor książek: Nierówności w świecie w świetle podstawowych zasad społecznych, Wrocław1999; Inspirujacy wplyw myśli Francisco de Vitoria na rozwój podstawowych praw czlowieka i wspólnoty międzynarodowej, Wrocław2009; Tęsknota w refleksji teologicznej, Wrocław 2016. 